\title{
A USINA HIDRELÉTRICA ESTREITO E A AMAZÔNIA NA POLÍTICA ENERGÉTICA BRASILEIRA: a desterritorialização dos camponeses ribeirinhos de Palmatuba (TO) ${ }^{1}$
}

\section{THE ESTREITO HYDROELECTRIC POWER PLANT AND THE AMAZON IN BRAZIL'S ENERGY POLICY: the deterritorialization of riparian farmers Palmatuba (TO)}

\author{
Airton Sieben \\ Professor do Programa de Pós-Graduação em Estudos de Cultura e Território (PPGCulT) \\ do Campus de Araguaína da Universidade Federal do Tocantins (UFT) \\ asieben@uft.edu.br \\ João Cleps Junior \\ Professor do Programa de Pós-Graduação em Geografia (PPGEO) do Instituto de \\ Geografia (IG) da Universidade Federal de Uberlândia (UFU) \\ jcleps@ufu.br
}

\section{Resumo}

O objetivo desta pesquisa foi analisar as políticas públicas de desenvolvimento territorial no Brasil e efeitos na Amazônia, estudando a barragem de Estreito e a desterritorialização dos camponeses de Palmatuba (Babaçulândia/TO) ocorrida no ano de 2009. Consultaram-se livros, instituições estatais, páginas da internet e aplicaram-se roteiros de entrevista às 25 famílias desterritorializadas no mês de setembro de 2014 . $\mathrm{O}$ Brasil aumentará a oferta de energia elétrica em torno de $60.00 \mathrm{Mw}$ entre o período de 2010/20, para atender às indústrias eletrointensivas. Além da geração elétrica, o grande capital (trans)nacional visualiza a mercantilização da água no futuro. Por outro lado, as famílias atingidas lutam por justiça nas indenizações, tentam se adaptar ao novo modo de vida e sentem saudades do antigo lugar.

Palavras-chaves: Território. Energia. Barragens. Mercantilização das águas. Rio Tocantins.

\begin{abstract}
The objective of this research was to analyze public policies of territorial development in Brazil and effects in the Amazon, studying the dam Estreito and the dispossession of peasants Palmatuba (Babaçulândia/TO) during the year 2009. Were consulted books, state institutions, websites and have applied interview scripts to 25 dispossessed families in September 2014. Brazil will increase the supply of electricity around $60.00 \mathrm{Mw}$ between the period $2010 / 20$ to meet the electricity-intensive industries. In addition to the power generation, the great capital (trans) national view water commodification in the future. On the other hand, the affected families fighting for justice in compensation, try to adapt to the new way of life and feel the old place miss.
\end{abstract}

Keywords: Territory. Energy. Dams. Commodification of water. Rio Tocantins. 
Introdução

A Amazônia brasileira se tornou uma fronteira energética diante do aumento de produção de energia elétrica no Brasil. A região Norte do Brasil tem potencial e imenso caudal para produzir eletricidade. Diante desta circunstância, inúmeras hidrelétricas estão em fase de implantação nas bacias hidrográficas dos rios Amazonas, Madeira, Araguaia e Tocantins. Estimam-se mais de quatrocentas hidrelétricas em toda a Amazônia, transformando esta região numa monocultura energética.

No estado do Tocantins, as políticas que atuam sobre o território intensificaram-se a partir da criação do estado, em 1988. Estudos realizados demonstraram como estas intervenções incidiram e incidem sobre o ambiente, as relações sociais, econômicas, culturais e políticas. Assim, se constroem e se mobilizam grupos de atores que constituem novas legitimidades, demandas e definem novos territórios e territorialidades.

As políticas de desenvolvimento do território rural tocantinense estão voltadas para os grandes projetos, como as hidrelétricas. Estas políticas, aliadas ao poder econômico, são responsáveis pelo processo de modernização do território, contrastando e entrando em conflito com o modo de vida de ribeirinhos que vivem às margens dos canais fluviais.

As formas unilaterais das decisões tomadas na política energética brasileira ocasionaram muitas famílias a ficarem sem terra, meios de produção e perspectivas de vida. Desta maneira, empreendimentos como a construção da Usina Hidrelétrica Estreito (UHEE) causou danos para as populações ribeirinhas e para o meio ambiente, tanto na parte física, como na econômica, social e cultural.

A UHEE foi implementada no decorrer do início do atual milênio. O Consórcio Estreito Energia (CESTE) foi o grupo ganhador da licitação no ano de 2002 para construir a represa. Este consórcio foi formado pelas empresas: GDF Suez (energia), a Vale (mineradora), a Alcoa (alumínio) e a Camargo Corrêa Energia (engenharia, construção e energia), tendo direito a concessão por 35 anos. A barragem foi construída na Amazônia Legal brasileira, no rio Tocantins, entre as cidades de Estreito (MA) e Aguiarnópolis (TO), atingindo dez municípios no estado da região Norte e dois no estado da região Nordeste.

Vários agentes sociais foram atingidos, dentre eles estão os índios, os vazanteiros, os barqueiros, os roceiros, as quebradeiras de coco babaçu, os pescadores e 
A Usina Hidrelétrica Estreito e a Amazônia na política energética brasileira: a desterritorialização dos camponeses ribeirinhos de Palmatuba (TO)
Airton Sieben João Cleps Junior

outros que tinham uma relação orgânica com o ambiente ribeirinho do rio Tocantins. Na comunidade Palmatuba havia pescadores, roceiros, vazanteiros, a quebra do coco babaçu, a confecção e a venda de artesanato desta palmeira.

A vila Palmatuba era considerada bairro da cidade de Babaçulândia, contudo o ambiente ribeirinho, as dificuldades de acesso e as atividades relacionadas à roça caracterizavam a comunidade como rural. De forma geral, a população abordada neste estudo caracterizou-se como classe camponesa.

Estudos e observações de campo revelaram que muitas dessas famílias estavam insatisfeitas e se dispersaram, vivendo um modo de vida diferente daquele cotidiano estabelecido na margem esquerda do rio Tocantins, pois não foram executadas políticas de reassentamento que pudessem minimizar os problemas dessa população.

Em muitos outros casos de atingidos por barragens as indenizações pagas foram baixas, dificultando o início de uma nova vida, além do sentimento de pertencimento ao território não ter sido considerado pelo empreendedor. No caso em estudo, ressalta-se que era uma comunidade isolada, constituída em sua maioria de pessoas idosas. Uma das grandes tarefas foi compreender a maneira como essas pessoas se adaptaram a outro modo de vida e como enfrentaram, enfrentam e enfrentarão esta situação após cinco anos de desterritorialização.

O presente artigo tem como objetivo principal analisar as políticas públicas de desenvolvimento territorial no Brasil, estudando a população camponesa amazônica do ex-povoado de Palmatuba. O local de estudo localizava-se no município de Babaçulândia, no estado do Tocantins e os ribeirinhos foram desterritorializados pela Usina Hidrelétrica Estreito.

\section{Metodologia e localização da área de estudo: o caminho da pesquisa}

No primeiro momento foram realizadas leituras sobre temas relacionados ao estudo tais como: políticas de desenvolvimento do território, barragens, efeitos socioambientais, entre outros. Os dados secundários consistiram na análise de políticas públicas e das dinâmicas socioeconômicas. As páginas da internet de órgãos oficiais como o Instituto Brasileiro de Geografia e Estatística (IBGE), Ministério de Minas e Energia (MME), Empresa de Pesquisa Energética (EPE), Agência Nacional das Águas 
A Usina Hidrelétrica Estreito e a Amazônia na política energética brasileira: a desterritorialização dos camponeses ribeirinhos de Palmatuba (TO)
Airton Sieben João Cleps Junior

(ANA) e Agência Nacional de Energia Elétrica (ANEEL) foram consultados a fim de analisar os relatórios sobre a demanda energética e as perspectivas futuras.

Com base nos relatórios obtidos nos órgãos citados, mesclando com análises de autores que estudam sobre o assunto, foi possível realizar observações sobre a questão elétrica no Brasil. Desta forma, foi possível traçar um quadro evolutivo até permear as influências da hidreletricidade na Amazônia brasileira, em especial na comunidade pesquisada.

Além de páginas da internet oficiais obtiveram-se dados no Instituto Nacional Colonização e Reforma Agrária (INCRA), Movimento dos Atingidos por Barragens (MAB) e Comissão Pastoral da Terra (CPT). A partir das informações obtidas nos documentos consultados elaboraram-se gráficos, tabelas e mapas, a fim de atingir os objetivos propostos na pesquisa em foco.

O trabalho realizado após cinco anos da formação do reservatório da UHE Estreito possibilitou estudos e comparações com a pesquisa efetuada e terminada no ano de 2012, que contou com coletas de campo realizadas no ano de 2010 (SIEBEN, 2012). Dessa forma, pesquisou-se a situação dos atingidos em cinco anos de emigração da população de Palmatuba.

Foi aplicado um roteiro de entrevista, contendo questões abertas e fechadas com os antigos moradores locais, para obtenção de informação sobre a renda familiar e a expectativa das famílias após a construção da barragem, envolvendo questões econômicas, sociais e culturais, a fim de verificar como esta população se identificou com os novos locais de moradia.

$\mathrm{O}$ roteiro de entrevistas fornece uma variedade de informações, as quais podem ser utilizadas de diversas formas no contexto da pesquisa. Mediante a tabulação de dados e informações oriundos desse instrumento de pesquisa, é possível elaborar quadros, tabelas, gráficos, mapas, textos transcritos dos entrevistados, entre outras possibilidades que enriquecem o trabalho do ponto de vista científico. (SIEBEN; CLEPS, 2013, p. 246).

O roteiro de entrevistas foi aplicado para as 25 famílias desterritorializadas de Palmatuba durante o mês de setembro, do ano de 2014. Em outras oportunidades tiraram-se fotos e reelaboraram-se algumas informações com os entrevistados a fim de esclarecer e corrigir dados e dúvidas. 
A Usina Hidrelétrica Estreito e a Amazônia na política energética brasileira: a desterritorialização dos camponeses ribeirinhos de Palmatuba (TO)
Airton Sieben João Cleps Junior

Whitaker (2002) assegura que se deve evitar o caráter caricatural das falas dos entrevistados, pois quando uma pessoa fala errado, ela não comete erros ortográficos, porque não está escrevendo. Pelo fato dos entrevistados se constituírem de pessoas simples, com pouco grau de instrução, as recomendações da autora são oportunas para não correr o risco de transcrever uma situação errônea, comprometendo a ética e a veracidade da pesquisa.

No âmbito desta pesquisa optou-se pela categoria camponês (MARTINS, 1981), como base teórica para caracterizar a classe social pesquisada, pelo modo de vida rural, com atividades relacionadas à roça, plantações, criações, extrativismo do coco babaçu e a localização geográfica de ribeirinho e a relação orgânica com o rio.

Nas pesquisas que envolvem seres humanos, proteger os pesquisados, respaldar o pesquisador e, sobretudo, atender aos critérios éticos na pesquisa são exigências para que o projeto seja avaliado por Comitê de Ética em Pesquisa envolvendo Seres Humanos (CEP). O projeto deve ser acompanhado de Termo de Consentimento Livre e Esclarecido (TCLE) e demais documentos que fazem parte do protocolo (BRASIL, Resolução, n 466/12, 2012).

O projeto foi avaliado e aprovado pelo CEP da Universidade Federal do Tocantins (UFT), localizado em Palmas (TO), no mês de agosto do ano de 2014, sob o Protocolo N. 065/2014. A peculiaridade da população composta por pessoas idosas, baixo grau de instrução e residências "isoladas" reforçaram a necessidade de aprovação de projeto em $\mathrm{CEP}^{2}$.

Outrossim, foram feitos levantamentos em campo que contribuíram para a formatação do trabalho com apresentação de dados e informações em tabelas e gráficos, mesclando a discussão numa visão fenomenológica sem aprofundar na questão do método. Esta medida foi importante para entender a situação enfrentada pelos atingidos, sobretudo nos quesitos de pertencimento e de lugar em uma região tão complexa em termos humanos, como na Amazônia.

As discussões envolvendo o território necessitam de análise cuidadosa, diante da situação imposta aos atingidos pelas barragens no Brasil. O caso dos atingidos pela UHEE não é diferente e a pesquisa em foco necessitou de análises críticas, mesmo sem aprofundar o método dialético para que as dificuldades enfrentadas pelos atingidos de Palmatuba fossem analisadas. 
A Usina Hidrelétrica Estreito e a Amazônia na política energética brasileira: a desterritorialização dos camponeses ribeirinhos de Palmatuba (TO)

O município de Babaçulândia fica localizado na Amazônia Legal brasileira, a $450 \mathrm{~km}$ de distância da capital do estado do Tocantins, Palmas. O município de Babaçulândia faz divisa com os municípios tocantinenses de Filadélfia (sul), Araguaína (oeste), Darcinópolis (noroeste) e Wanderlândia (norte). Na porção leste localiza-se o rio Tocantins, fazendo divisa com o município maranhense de Carolina (Mapa 1).

Mapa 1 - Localização do ex-povoado de Palmatuba e da UHEE

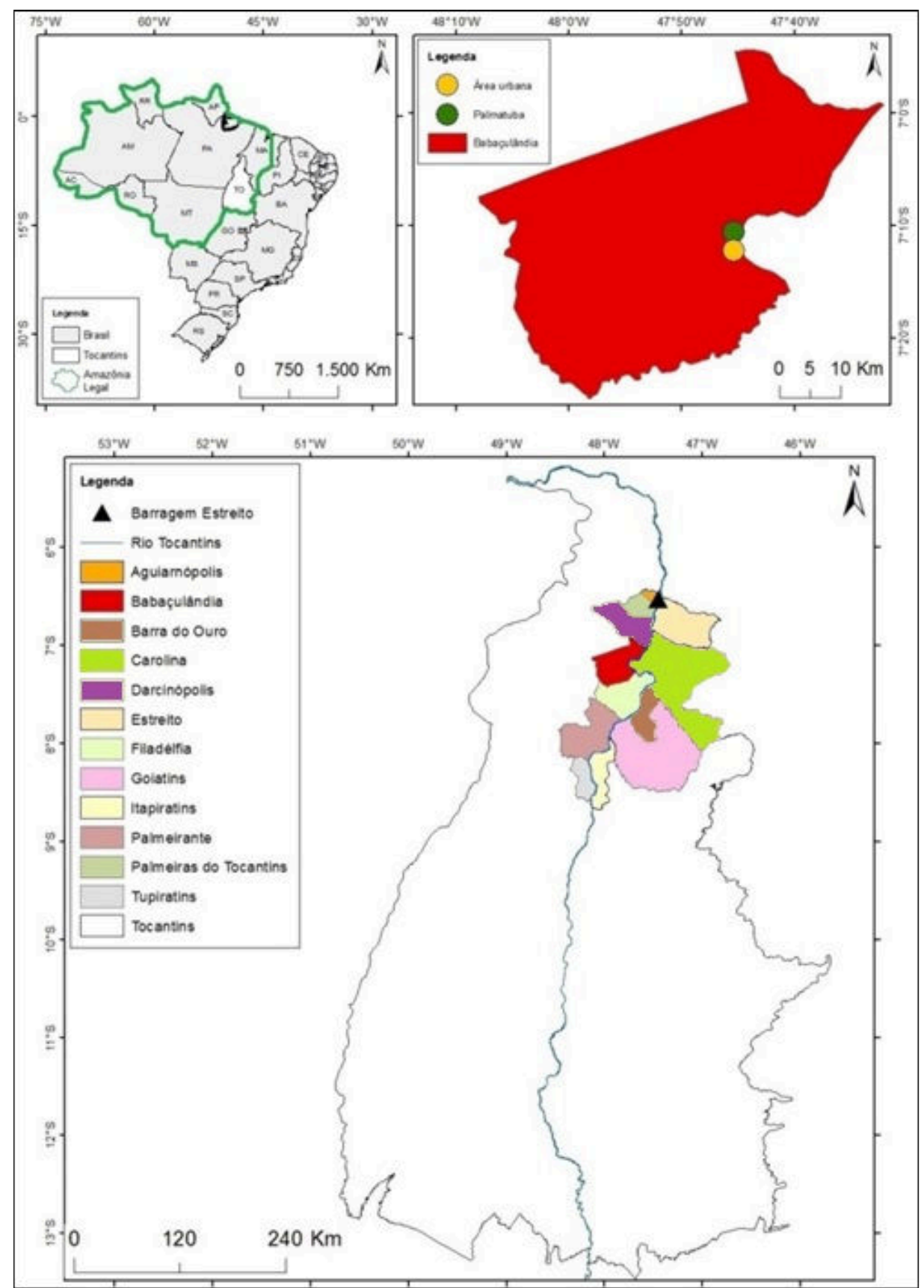

Fonte: IBGE, 2004/2006.

Org. Sieben, 05/2015. 
A Usina Hidrelétrica Estreito e a Amazônia na política energética brasileira: a desterritorialização dos camponeses ribeirinhos de Palmatuba (TO)
Airton Sieben João Cleps Junior

A cidade de Babaçulândia localiza-se à margem esquerda do rio Tocantins. $\mathrm{O}$ mapa 1 mostra o bairro Palmatuba que era distante aproximadamente cinco $\mathrm{km}$ do centro da cidade de Babaçulândia. Considerando o rio Tocantins, à jusante de Babaçulândia estão localizados os municípios de Aguiarnópolis (TO) e Estreito (MA). Aguiarnópolis e Estreito se localizam ao norte do estado do Tocantins e a sudoeste do estado do Maranhão, respectivamente. É no município nordestino que ficaram as maiores obras, inclusive a casa de máquinas.

O lago atinge as cidades e áreas rurais dos municípios de Babaçulândia e Filadélfia e área rural dos municípios de Darcinópolis e Wanderlândia (TO). No estado do Maranhão atinge as áreas urbana e rural do município de Carolina e, em Estreito, a barragem foi construída a montante da cidade e o reservatório atinge a área rural daquele município.

Ao todo, doze municípios foram atingidos pelo reservatório, sendo dez do estado nortista e dois do estado nordestino. As populações atingidas seguiram diversos rumos, algumas foram alojadas em reassentamentos nos estados do Tocantins e do Maranhão. Em torno de 4.500 pessoas foram atingidas conforme dados do EIA/Rima (CNEC, 2001).

A população atingida de Palmatuba emigrou para cidades e áreas rurais dos municípios de Araguaína, Aragominas, Babaçulândia, Wanderlândia, no estado do Tocantins e Carolina no estado do Maranhão. Os efeitos das hidrelétricas nas populações atingidas são vários e mais pessoas serão obrigadas a emigrar com a perspectiva futura na geração energética brasileira.

\section{As perspectivas da energia hidrelétrica no Brasil}

A energia é importante para o crescimento econômico de qualquer país, estado, região ou localidade. Historicamente, as nações que se desenvolveram necessitaram de energia para transformarem matéria prima, além de facilitar e aumentar a produtividade do trabalho. Neste sentido, quanto mais energia mais desenvolvimento e progresso.

No hay desarrollo sin energía, por ende, las dos realidades hacen una sola. No podemos escribir la historia de la una sin abordar la de la otra. No se trata de un hecho solamente material, sino también de un entrelazamiento cultural que alcanza inevitablemente dimensiones políticas. La utilización de la energía forma parte integrante, entonces, de lo que pudiéramos llamar dinamismo humano. (HOUTART, 2009, p. 5). 
A Usina Hidrelétrica Estreito e a Amazônia na política energética brasileira: a desterritorialização dos camponeses ribeirinhos de Palmatuba (TO)
Airton Sieben João Cleps Junior

A energia é importante para transformar a matéria prima nas indústrias. No Brasil é a indústria que demanda praticamente $50 \%$ da energia consumida no país. O gráfico 1 apresenta a distribuição no consumo de energia por setor e quanto representou cada segmento no consumo de energia, tendo como base o ano de 2004.

Gráfico 1 - Consumo de energia elétrica nos principais setores: foco indústria (2004)

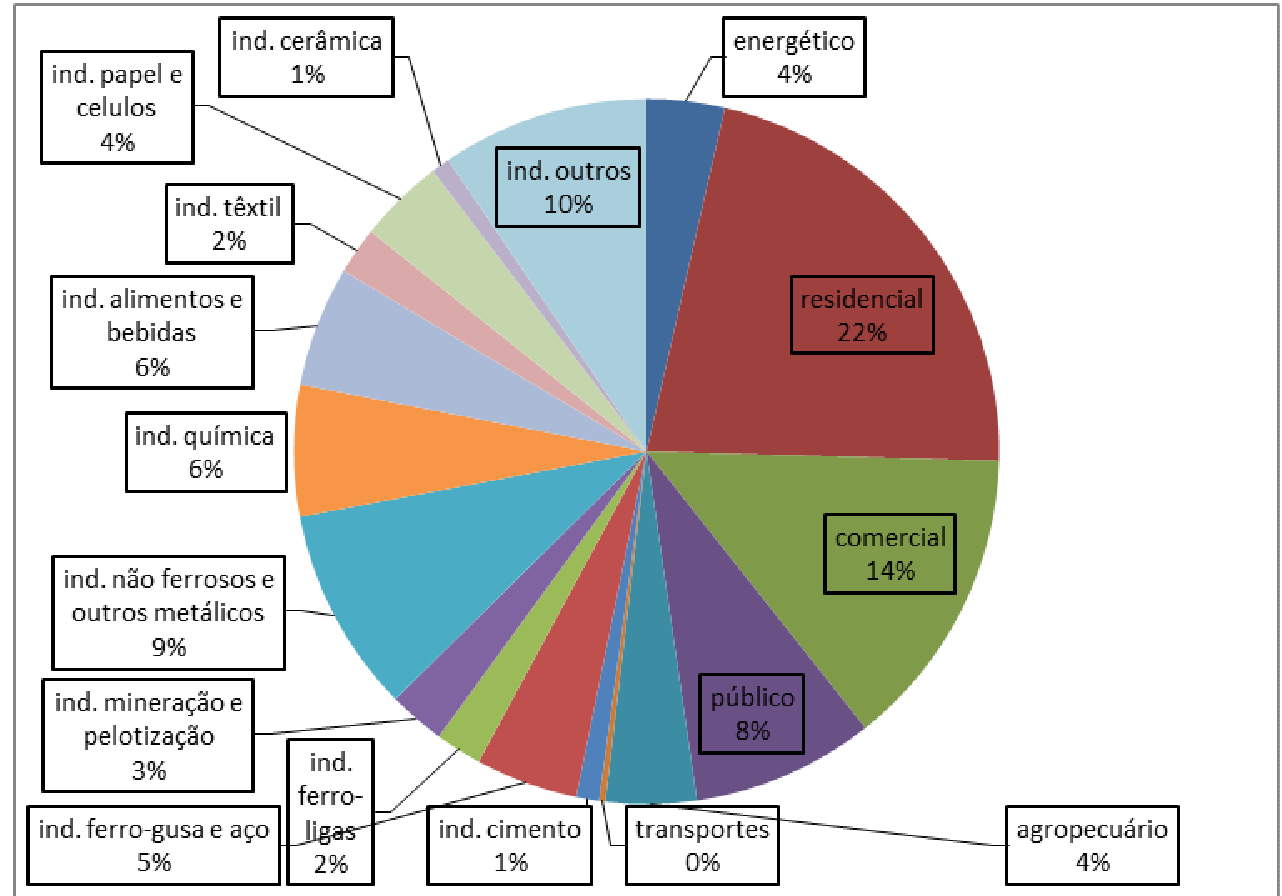

Fonte: Brasil, 2007.

Org. Sieben: 08/2014.

No gráfico 1 nota-se que os setores residencial, comercial e público consumiram $22 \%, 14 \%$, e $8 \%$ de energia, respectivamente. O setor energético e o setor agropecuária consumiram $4 \%$ de energia cada um. Por sua vez, o consumo dos transportes, representado pelo ferroviário, ficou próximo de $0 \%(0,4 \%$ exatamente).

As indústrias de cimento e cerâmica consumiram $1 \%$ de energia cada uma. As indústrias de ferro-ligas e têxtil consumiram $2 \%$ de energia cada uma. As indústrias de mineração e pelotização, papel e celulose e ferro-gusa e aço consumiram 3\%, 4\% e 5\% de energia, respectivamente. As indústrias química, de alimentos e bebidas consumiram $6 \%$ de energia cada uma. A indústria de materiais não ferrosos e outros metálicos consumiu em 2004 9\% da energia, cabendo às demais indústrias o consumo dos outros $10 \%$. No total, o setor industrial consumiu $49 \%$ de energia (Gráfico 1). 
Parece ficar evidente a resposta da pergunta 'energia para quê e para quem?'. Uma considerável quantidade de energia elétrica gerada no Brasil está a serviço de um pequeno grupo econômico representado pelos proprietários das indústrias eletrointensivas; estes se apossaram, inicialmente, do Estado e na atualidade buscam se apropriar de recursos naturais para garantirem maiores lucros para seus investimentos, controlando seus próprios territórios. Esse domínio sobre a energia serve para garantir menores custos aos seus produtos, que conseguem concorrer no mercado internacional, um dos mais importantes locais de negociação dos mesmos, garantindo, assim, uma lucratividade alta para seus negócios. (FOSCHIERA, 2009, p. 130).

No gráfico 2 percebe-se a evolução final do consumo elétrico por setor para os anos de 1970, 1990, 2010 e 2030 (Estimativas do Plano Nacional de Energia - PNE). Nota-se que os setores de transporte e o agropecuário demandam pouco consumo de energia, mantendo o seu consumo estável sem grandes mudanças em termos proporcionais, havendo estabilidade nestes setores para os anos de 2010 e 2030. Neste período, é nítido um leve aumento na participação do setor agropecuário, mas se apresenta com consumo inferior a $5 \%$, da mesma forma que o setor transporte.

Gráfico 2 - Brasil (1970-2030): evolução do consumo elétrico por setor (\%)

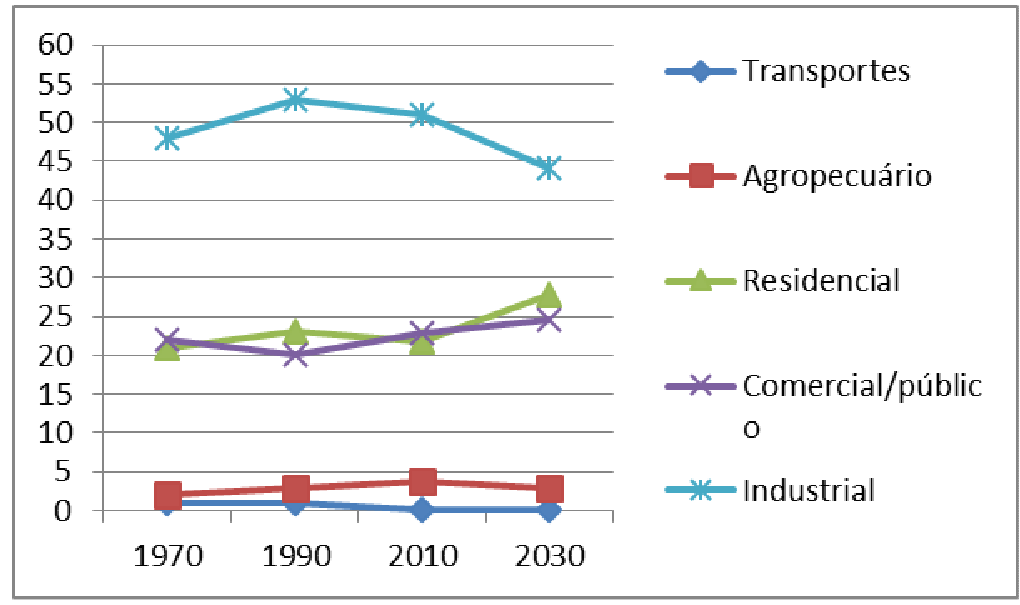

Fonte: Brasil, 2007.

Org. Sieben: 11/20014.

O pouco consumo elétrico do setor transporte apresentado no gráfico 2 mostra que não haverá mudança na matriz energética que movimenta os veículos, baseada no petróleo e em algumas alternativas como o etanol. Neste cenário, é perceptível que os "sonhados" caros elétricos não chegarão tão cedo ao mercado brasileiro ou pelo menos não em grande quantidade, pois o consumo elétrico no setor transporte é utilizado no setor ferroviário, sobretudo nas cidades. 
A Usina Hidrelétrica Estreito e a Amazônia na política energética brasileira: a desterritorialização dos camponeses ribeirinhos de Palmatuba (TO)
Airton Sieben João Cleps Junior

Conforme o gráfico 2, os setores residenciais e comerciais públicos se alternam na segunda colocação quanto ao consumo entre os anos 1970 e 2030. Em 1970 o setor comercial/público era o segundo no consumo elétrico, perdendo para o industrial. A mesma situação foi apontada no ano de 2010. O setor residencial teve maior consumo no ano de 1990, a mesma situação é apontada para o ano de 2030, quando este setor consumirá mais energia que o comercial público.

A maior inserção de brasileiros no consumo energético, a disponibilização das redes elétricas em locais mais longínquos no Brasil aumentarão esta demanda para o setor residencial. As políticas públicas como o "Luz Para Todos", a maior aquisição de aparelhos eletrodomésticos e o "fetiche" do consumismo ampliarão a necessidade elétrica para os brasileiros no setor residencial.

Os setores comercial/público e residencial manterão um aumento constante entre o período de 2010/30. Nos anos de 1970, cada setor consumia uma faixa compreendida entre 20 e $25 \%$ e esse cenário se manteve até o ano de 2010 . No cenário futuro a participação de cada um destes dois setores ficará entre a faixa de 25 e 30\% (Gráfico2).

O setor industrial continuará como o maior consumidor de energia elétrica no Brasil (Gráfico 2). É perceptível que nos anos de 1970 este setor consumia entre 45 e $50 \%$ da energia elétrica no Brasil. Nos anos de 1990 e 2010, o setor industrial aumentou o consumo de energia para a faixa compreendida entre 50 e $55 \%$, apresentando queda no período compreendido entre os anos de 2010/30.

No cenário futuro o setor industrial retornará ao consumo entre 40 e $45 \%$ do total de energia elétrica consumida no Brasil, pois os outros setores demandarão maior consumo em termos proporcionais, com leve aumento de consumo energético nos setores residencial e comercial/público. Mesmo ocorrendo queda futura na participação do setor industrial, isto não mostra que a atual política elétrica esteja voltada para os outros setores, mas sim como reflexo da maior oferta de consumo de energia que todos os setores demandarão.

O gráfico 3 apresenta a comparação da matriz energética brasileira entre os anos de 2010 e 2020. É perceptível a importância das hidrelétricas no fornecimento de energia no ano de 2010 e no ano de 2020. Percebe-se relativa contribuição das energias provenientes de óleo combustível, biomassa e eólica, sobretudo esta última, mas as demais permanecem praticamente estagnadas. Estas três contribuirão aproximadamente com 30 mil MW dos 170 mil MW no ano de 2020. 
A Usina Hidrelétrica Estreito e a Amazônia na política energética brasileira: a desterritorialização dos camponeses ribeirinhos de Palmatuba (TO)

Airton Sieben

Contudo, o aumento da produção de energia eólica e outras fontes alternativas (Gráfico 3) não significa a diminuição do fornecimento de hidroeletricidade. As usinas eólicas servem somente para aumentar a demanda energética, não contribuindo como alternativa para as usinas hidrelétricas.

O cenário apresentado no gráfico 3 é preocupante, pois se percebe que a matriz elétrica está direcionada e refém de uma única fonte principal (hidrelétrica), fragilizando de forma exagerada o sistema elétrico nacional. No cenário atual e futuro se ocorrer algum problema de gestão, operacionalização, climático ou econômico, deixará o país sem energia e, portanto, sem desenvolvimento, caso não se amplie e diversifique com outras energias renováveis.

Gráfico 3 - Brasil: comparação da matriz energética em MW (2010/2020)

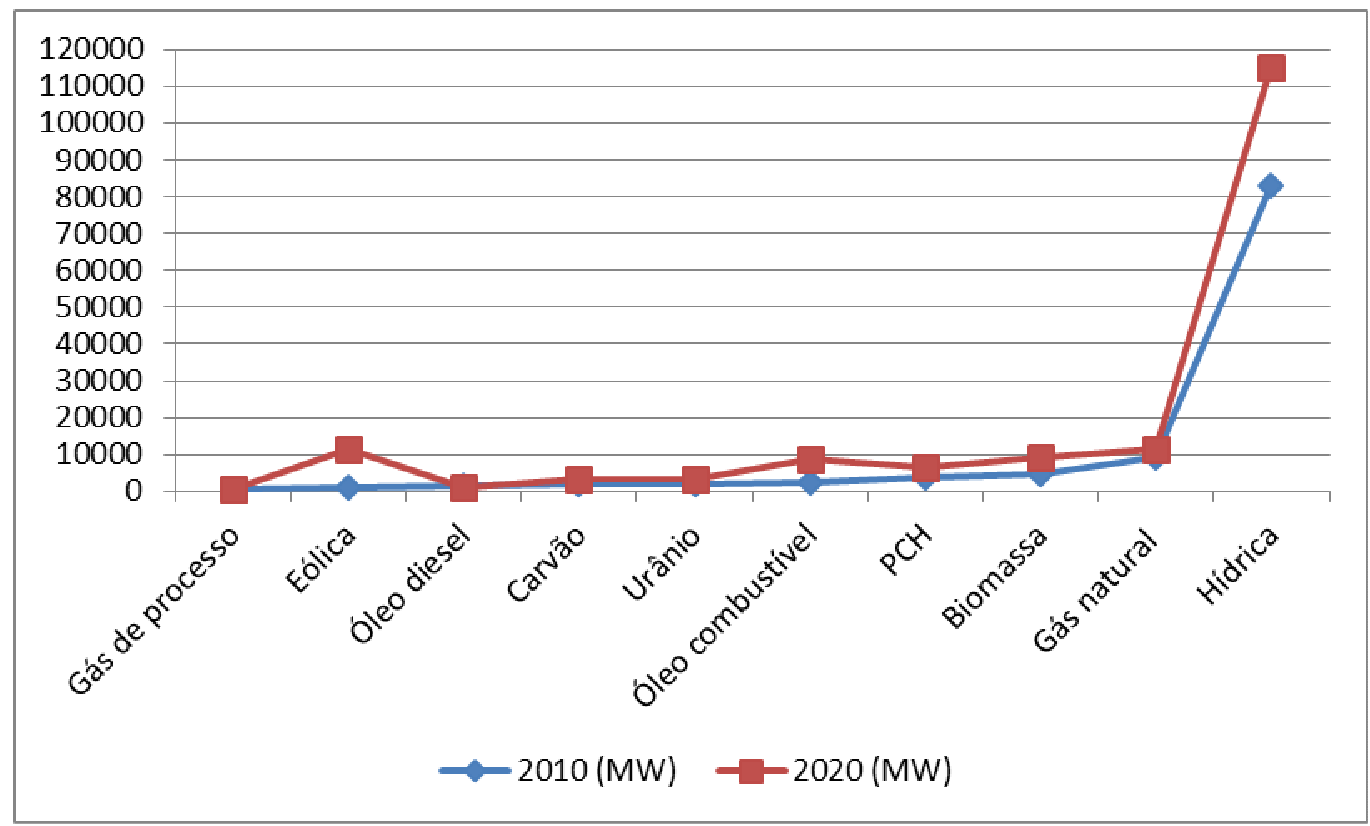

Fonte: Brasil, 2011.

Org. Sieben, 11/2014.

Destarte, evidencia-se que a água virou um negócio para o capital. De forma geral, havia dúvidas de como se daria a apropriação da Amazônia e da sua água, há certo tempo atrás. No momento, estes pontos podem-se clarificar e há indicativos de como é tratada e será utilizada a Amazônia, na atual e futura conjuntura política e econômica. 
A Usina Hidrelétrica Estreito e a Amazônia na política energética brasileira: a desterritorialização dos camponeses ribeirinhos de Palmatuba (TO)
Airton Sieben João Cleps Junior

Amazônia brasileira: hidreletricidade e efeitos nas populações atingidas

Diante da necessidade e previsão de oferta de energia elétrica para os próximos anos surge a pergunta: como o Brasil gerará tanta eletricidade? Sabe-se que a eficiência do potencial hidrelétrico no Brasil é enorme, mas o potencial hidrelétrico dos rios brasileiros gera problemas para as populações que mantêm relações orgânicas com os rios. A forma de o governo atuar e se organizar em relação as hidrelétricas podem ser traduzidas no atual quadro de potencial hidrelétrico apresentado em dados $\mathrm{e}$ informações sobre a Amazônia para o período 2010/ 2020.

O gráfico 4 mostra a oferta de energia no horizonte de dez anos, ou seja, entre 2010 e 2020. Conforme o gráfico, os sistemas das regiões Sudeste/Centro Oeste, Sul, Nordeste e Norte ofertaram 65.594, 17.808, 15.523 e 10.653MW de energia, respectivamente, no ano de 2010. Em termos proporcionais, as regiões Sudeste/CO, Sul, Nordeste e Norte, respectivamente, ofereceram 60\%, 16\%, 14\% e 10\% dos $109.578 \mathrm{MW}$ elétricos.

Gráfico 4 - Eletricidade: participação regional e potência instalada 2010/2020 (MW)

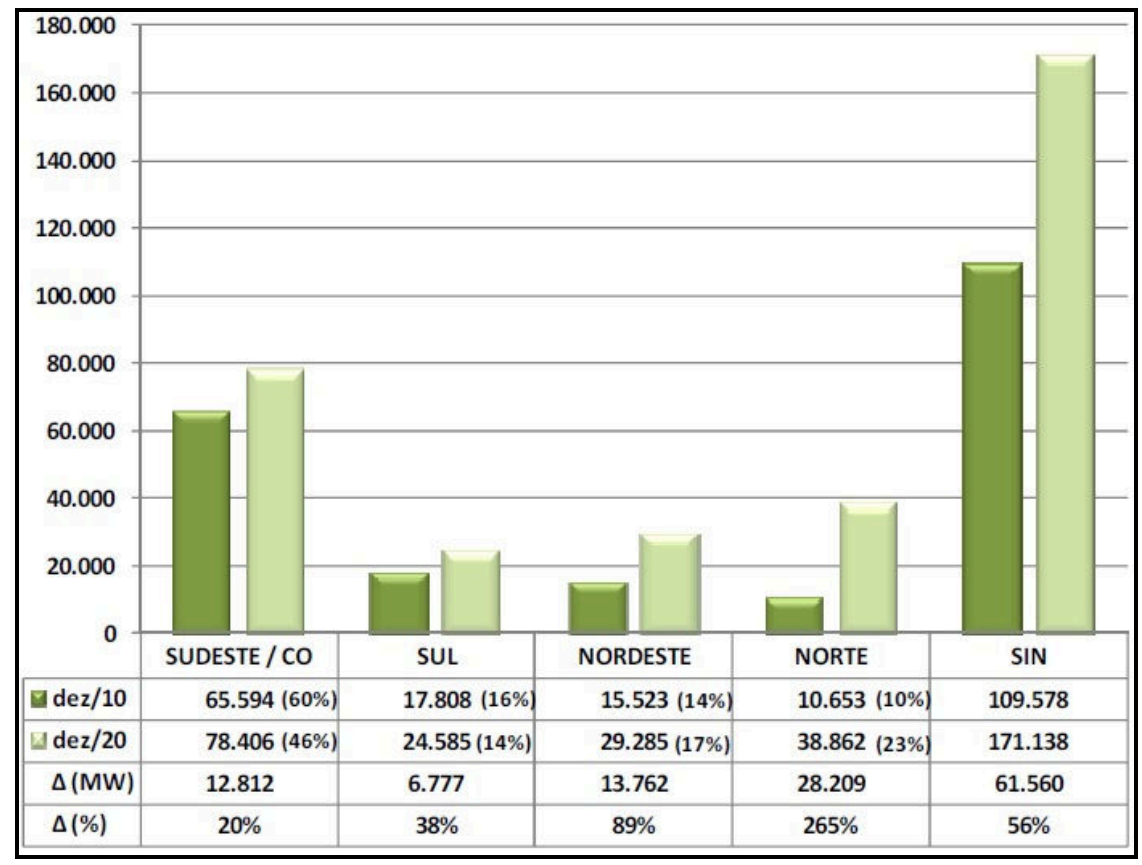

Fonte: Brasil, 2011.

Org. Sieben 11/2014.

Para o ano de 2020 os sistemas Sudeste/CO aumentarão para 78.406MW com $46 \%$ e a região Sul ficará com 24.585MW (14\%) do total geral. Por sua vez, as regiões 
A Usina Hidrelétrica Estreito e a Amazônia na política energética brasileira: a desterritorialização dos camponeses ribeirinhos de Palmatuba (TO)
Airton Sieben João Cleps Junior

Nordeste e Norte aumentarão a oferta para $29.285 \mathrm{MW}$ e $38.862 \mathrm{MW}$, respectivamente.

Estas duas regiões produzirão 17\% (Nordeste) e 23\% (Norte) da energia do Brasil, conforme o gráfico 4 .

Observa-se que o Sistema Interligado Nacional (SIN) aumentará a oferta de energia de 109.578MW no ano de 2010, para 171.138MW no ano de 2020. Isso significa um aumento de 61.560MW (56\%) em uma dezena de anos. Todas as regiões produzirão mais energia, respetivamente, $28.209 \mathrm{MW}, 13.762 \mathrm{MW}, 6.777 \mathrm{MW} 12.812 \mathrm{MW}$ para os sistemas Norte, Nordeste, Sul e Sudeste/CO. Em termos proporcionais isto acarretará na incorporação elétrica de $265 \%, 89 \%, 38 \%$ e $20 \%$ para os sistemas regionais Norte, Nordeste, Sul e Sudeste/CO, respectivamente conforme o gráfico 4.

O gráfico 4 mostra que as regiões Sudeste/CO e Sul, em termos proporcionais diminuirão a oferta de energia, baixando suas contribuições, de $60 \%$ para $46 \%$ (Sudeste/CO) e de 16\% para 14\% (Sul). Por sua vez, a s regiões Nordeste e Norte aumentarão a oferta de energia, ultrapassando o sistema Sul. As regiões Nordeste e Norte aumentarão o potencial de $14 \%$ para $17 \%$ e de 10 para $23 \%$, respectivamente.

No ano de 2010 as regiões Sudeste/CO e Sul produziam 76\% de energia, enquanto os sistemas Nordeste e Norte ofereciam 24\%. Para o ano de 2020 ocorrerá uma igualdade nas proporções, pois as regiões Nordeste e Norte oferecerão $40 \%$ de energia e região Centro-Sul caberão $60 \%$ (Gráfico 4). Isto não significa dizer que a demanda será mantida nas mesmas proporções para cada região.

A atuação do SIN no planejamento energético nacional prevê que regiões com maior potencial elétrico possam ser utilizadas em maior escala diante a um período de seca em outras regiões. Mesmo com todo o planejamento por parte do SIN o quadro de dependência da hidreletricidade não mudará no quadro futuro, acarretando em riscos ao setor.

As regiões Sul e Sudeste concentram maior contingente populacional, além de serem as regiões mais industrializadas do Brasil, destacando-se o estado de São Paulo. Este estado da região Sudeste é o mais industrializado e populoso do Brasil e, por isso, necessita grandes quantidades de energia.

Com o crescimento econômico e populacional previsto são evidentes os desafios do setor energético. A capacidade instalada de nosso parque gerador de energia elétrica deverá crescer $56 \%$ na próxima década, representando um aumento aproximado de 6 mil megawatts anuais. O Sistema Interligado Nacional, responsável pelo escoamento 
de toda essa energia, deverá crescer $43 \%$, alcançando 142 mil quilômetros de linhas de transmissão. (BRASIL, 2011, p. 5).

Para a região Norte esta situação implicará em uma série de problemas econômicos, sociais, culturais e ambientais, pois as águas das barragens ocasionarão a desterritorialização de vários camponeses, comunidades e povos tracionais. Os efeitos serão maiores para os povos indígenas e outras classes sociais que mantêm relação orgânica com os grandes rios da região Amazônica.

Essa nova realidade estaria coerente com o fato de a Amazônia dispor de $20 \%$ do sistema hidrográfico do planeta, um caudal de águas que poderia proporcionar a geração de 50 mil megawats de energia, apenas $15 \%$ menos do que a produção total do Brasil no momento. No espaço de apenas três décadas, o ingresso da Amazônia no mercado energético nacional quase provocaria a duplicação da geração. (PINTO, 2002, p. 46).

A cobiça sobre a região Amazônica é grande por causa da diversidade em riquezas representadas em minérios, reservas e por deter $1 / 5$ das reservas mundiais de água doce em rios. "Esse desempenho realmente impressionante talvez esteja ofuscando a percepção de um fato: a especialização dos rios amazônicos na monocultura energética" (PINTO, 2002, p. 47).

Assim, a Amazônia será uma monocultura com finalidade energética como apresentou Pinto (2002). Como em toda monocultura os rejeitos serão locais, enquanto os beneficiados estarão localizados longe dali atendendo as necessidades capitalistas. A região Norte não necessita e nem consumirá toda esta produção energética que será utilizada em outras regiões do país, atendendo à população e, sobretudo, às indústrias.

Para além dos lucros financeiros com a geração de energia, outro ponto de debate é a garantia de domínio da água dos reservatórios. Previsões feitas destacam a escassez de água no futuro e que passaria a ser uma mercadoria de alto valor. Além do lucro com a geração de energia, as empresas estariam garantindo mais uma mercadoria que lhes renderá grandes vantagens no futuro, a água. (FOSCHIERA, 2009, p. 274).

A produção elétrica é um primeiro passo para a monopolização da água e no futuro próximo poderá fornecer alto valor especulativo na mercadoria água, concentrada nas mãos de poucas empresas que detêm e controlam o poder absoluto sobre os reservatórios das grandes barragens brasileiras. Dessa forma, ter-se-á a concentração dos rios e reservatórios o que caracterizaria uma monopolização das águas. Nos projetos 
A Usina Hidrelétrica Estreito e a Amazônia na política energética brasileira: a desterritorialização dos camponeses ribeirinhos de Palmatuba (TO)
Airton Sieben João Cleps Junior

estatais o monopólio da água está camuflado na necessidade de expansão elétrica e na construção das linhas de transmissão.

Há 109 projetos de linhas de transmissão analisados e dentre eles, 23 (21\%), 12 $(11 \%), 65(60 \%)$ e $9(8 \%)$ estão localizados, respectivamente, nos subsistemas das regiões Norte, Nordeste, Sudeste/Centro-Oeste e Sul. Ao final deste decênio o país contará com 142 mil km de linhas de transmissão.

Salienta-se que muitas destas linhas de transmissão beneficiarão os locais de destino de energia que não coincidem com os locais de produção da mesma. "[...] a necessidade de que as regiões Sudeste/Centro-Oeste e Sul ampliem sua capacidade de recebimento de outras regiões" (BRASIL, 2011. p. 26). Assim, os relatórios oficiais esclarecem que os locais de geração de energia não serão os mesmos de consumo.

A tabela 1 apresenta dados referentes à expansão da oferta de energia elétrica na Amazônia entres os anos de 2011 a 2021. Neste período, estão previstos 44.016MW de energia oriundas da Amazônia com a construção de 25 hidrelétricas. Até o ano de 2014 entraram em operação seis barragens, totalizando 8.695MW. Para o ano de 2015 foram previstas mais quatro hidrelétricas, totalizando $13.605 \mathrm{MW}$, destacando-se os 11.233MW da controvertida Usina Hidrelétrica de Belo Monte.

Entre os anos de 2016 e 2019 entrarão em operação mais oito hidrelétricas, totalizando 10.866MW, destacando-se a Usina Hidrelétrica de São Luiz dos Tapajós que produzirá 6.133MW, localizada no estado do Pará, represando o rio Tapajós. Nos anos de 2020/21 entrarão em operação sete barragens, sendo quatro grandes empreendimentos com produção acima de $1.000 \mathrm{MW}$. As sete usinas produzirão 10.850MW, sendo que 7.130MW serão incorporados no ano de 2021 (Tabela 1).

Ao todo serão onze grandes hidrelétricas com capacidade de geração de energia superior a $1.000 \mathrm{MW}$ (Tabela 1). O rio Tocantins contribuirá com três grandes hidrelétricas gerando 4.775MW (aproximadamente 10\%), destacando que 1.087MW já são produzidas pela Usina Hidrelétrica Estreito, que entrou em operação no ano de 2011 e foi objeto deste estudo.

Os estados do Pará e do Mato Grosso terão maior número de hidrelétricas construídas em seu território, totalizando dezoito, nove atingindo cada estado. $\mathrm{Na}$ sequência, os estados de Rondônia e Tocantins com três barragens atingindo cada 
A Usina Hidrelétrica Estreito e a Amazônia na política energética brasileira: a desterritorialização dos camponeses ribeirinhos de Palmatuba (TO)
Airton Sieben João Cleps Junior

estado. Os estados do Amapá e do Maranhão serão atingidos por quatro hidrelétricas, duas representantes em cada estado, conforme tabela 1 .

Todas as barragens serão construídas nas bacias hidrográficas dos rios Amazonas e Araguaia-Tocantins (Tabela 1). A maior parte das hidrelétricas será construída na margem direita do rio Amazonas, com exceção das usinas de Santo Antônio do Jari e Ferreira Gomes que atingirão o estado do Amapá na margem esquerda do rio Amazonas e as barragens construídas na bacia hidrográfica dos rios Araguaia-Tocantins.

Tabela 1 - Expansão hidrelétrica na Amazônia brasileira (2011/2021)

\begin{tabular}{|c|c|c|c|c|}
\hline Início de operação & Projeto & Rio & UF & Potência (MW) \\
\hline 2011 & Estreito & Tocantins & TO & 1087 \\
\hline 2011 & Dardanelos & Arapuanã & MT & 261 \\
\hline 2012 & Rondon II & Comemoração & RO & 74 \\
\hline 2012 & Santo Antônio & Madeira & RO & 3150 \\
\hline 2013 & Jirau & Madeira & RO & 3750 \\
\hline 2014 & Santo Antônio do Jari & Jari & $\mathrm{AP} / \mathrm{PA}$ & 373 \\
\hline 2015 & Ferreira Gomes & Araguari & $\mathrm{AP}$ & 252 \\
\hline 2015 & Colider & Teles Pires & MT & 300 \\
\hline 2015 & Belo Monte & Xingu & $\mathrm{PA}$ & 11233 \\
\hline 2015 & Teles Pires & Teles Pires & MT & 1820 \\
\hline 2016 & Foz do Apiacás & Apiacás & MT & 230 \\
\hline 2017 & Sinop & Teles Pires & MT & 400 \\
\hline 2017 & São Manoel & Teles Pires & MT & 700 \\
\hline 2017 & Cachoeira Caldeirão & Araguari & $\mathrm{AP}$ & 219 \\
\hline 2017 & Água Limpa & Das Mortes & MT & 320 \\
\hline 2018 & São Luíz do Tapajós & Tapajós & PA & 6133 \\
\hline 2019 & Cachoeira dos Patos & Jamanxin & $\mathrm{PA}$ & 528 \\
\hline 2019 & Jatobá & Tapajós & $\mathrm{PA}$ & 2336 \\
\hline 2020 & Bem Querer & Branco & $\mathrm{RR}$ & 709 \\
\hline 2020 & Jamanxin & Jamanxin & PA & 881 \\
\hline 2020 & Cachoeira do Caí & Jamanxin & $\mathrm{PA}$ & 802 \\
\hline 2020 & Serra Quebrada & Tocantins & TO/MA & 1328 \\
\hline 2021 & São Simão Alto & Jurena & MT/PA & 3509 \\
\hline 2021 & Marabá & Tocantins & $\mathrm{PA} / \mathrm{TO} / \mathrm{MA}$ & 2160 \\
\hline 2021 & Salto Augusto Baixo & Jurena & MT & 1461 \\
\hline Total & & & & 44016 \\
\hline
\end{tabular}

Fonte: Brasil, 2012; Alves, 2014.

Org. Sieben, 11/2014. 
A Usina Hidrelétrica Estreito e a Amazônia na política energética brasileira: a desterritorialização dos camponeses ribeirinhos de Palmatuba (TO)
Airton Sieben João Cleps Junior

$\mathrm{Na}$ Amazônia brasileira meridional e ocidental, os estados produtores de hidreletricidade coincidem com as áreas, onde o desmatamento, o agronegócio e a exploração mineral estão atuando com voracidade para incorporar a região ao capitalismo nacional/internacional. Por outro lado, as comunidades e povos que residem nesta região há vários anos sofrem os efeitos da atuação de acumulação capitalista.

A tabela 1 mostra a entrada em operação ininterrupta de hidrelétricas na Amazônia durante o período de 2011 a 2021, caracterizando uma dependência cada vez mais consolidada pelo oligopólio da hidreletricidade. Assim, percebe-se a função da região Norte na produção hidrelétrica, transformado o espaço regional em monocultura energética.

Salienta-se que apesar dos dados e das estimativas oficiais sobre a construção de barragens, algumas hidrelétricas estão com o seu cronograma atrasado. Um dos motivos pelo atraso da construção e finalização de algumas barragens é o atual quadro de instabilidades política e econômica enfrentadas pelo Brasil.

A Amazônia e todo o Brasil têm problemas semelhantes a todas as outras nações latino americanas. A América Latina como um todo está subordinada ao grande capital das economias centrais. As instabilidades econômicas e política da América Latina obrigam estes países a se subordinarem às regras impostas pelas economias desenvolvidas centrais com o apoio de governantes locais, desde o "descobrimento" das Américas.

Los pueblos latino-americanos y los indígenas nortemaricanos han luchado a lo largo de cinco siglos contra todas las formas de opresión y discriminación impuestas, tanto por las potencias extranjeras como por los gobiernos que han representado los intereses de aquellas y se han subordinado al capital foráneo. Por eso, la reflexión latinoamericana ha tenido como tema central el problema del hombre y específicamente el latinoamericano, sus preocupaciones, sus angustias, sus relaciones de semejanzas y diferencias com otros hombres. (DÍAZ, 2012, p. 36)

A mercantilização e o monopólio da água para a produção da mercadoria energia impõe a racionalidade do capital sobre a cultura, a sociedade, os modos de vida, a economia e a territorialização autóctone de comunidades tradicionais, extrativistas, camponeses, indígenas e outras classes que têm seus modos de vida atrelados ao ambiente ribeirinho da Amazônia. Chama a atenção o processo de acúmulo e concentração do capital em detrimento das classes sociais elencadas. 
É neste ponto que nossas preocupações se põem para entender o atual contexto de inserção da Amazônia na dinâmica de acumulação do capital (nacional e internacional) como a nova fronteira hidroenergética nacional, respaldada pela atuação do Estado, em especial pelas políticas públicas específicas para o setor elétrico nacional, a partir do governo do Presidente Luiz Inácio Lula da Silva, via PAC. É nesse ambiente que se tornam recorrentes e complexas tramas de relações que se materializam nas formas degradantes do trabalho nas grandes obras de produção de energia hidrelétrica. (ALVES, 2014, p. 114).

O domínio sobre as riquezas amazônicas representa a concentração do capital e o aumento das desigualdades sociais, sem ocorrer a reestruturação de classe no Brasil. Não há divisão das riquezas e a classe trabalhadora não se beneficiará das riquezas geradas com todo o processo de apropriação da natureza e desterritorialização autóctone motivada pelo capital. Destarte, os desejados e justos desenvolvimentos socioeconômicos não se concretizarão no país.

\begin{abstract}
Em suma, em cada momento histórico o Estado atua na mediação dos pactos de dominação de classe, para a apropriação da riqueza produzida pelos trabalhadores que é apropriada, dentro dos marcos regulatórios e jurídicos, em benefício daqueles setores ou classes que controlam e/ou exercem maior poder sobre a instituição Estado. Como falamos de um Estado burguês, esses pactos de dominação são condições necessárias para a manutenção das condições de reprodução ampliada do capital e para a perpetuação do status quo. (ALVES, 2014, p. 121).
\end{abstract}

Para as comunidades atingidas resta o sacrifício de perderem suas terras, parte de sua história e o modo de vida, ou seja, a desterritorialização como futuro incerto e uma nova vida por construir. Este é o caso em estudo exemplificado pela desterritorialização dos camponeses de Palmatuba atingidos pela Usina Hidrelétrica Estreito, cujo direito de concessão perdurará por 35 anos a um grupo de empresas de capital nacional e internacional.

\title{
Hidrelétricas na Amazônia: o significado para os atingidos de Palmatuba
}

A comunidade de Palmatuba vivia no município de Babaçulândia, no estado do Tocantins, na margem esquerda do rio Tocantins e construiu uma história de vida durante 80 anos. Esta população era emigrante de estados nordestinos e encontrou naquela localidade um modo de vida relacionado ao ambiente ribeirinho. 
No início do milênio atual a população se deparou com um acontecimento que mudou suas vidas drasticamente: a chegada da UHE Estreito. A população sabia da necessidade de energia elétrica, mas a pergunta era: por que nós? Em sua visão, a comunidade vivia tranquila, produzindo para o sustento, vendendo o excedente nas feiras da cidade e trabalhando com o artesanato do coco babaçu.

No ano de 2009 as 25 famílias foram expropriadas, cada uma seguiu seu caminho, pois não houve reassentamento coletivo, como era o objetivo de algumas famílias. A população atingida de Palmatuba espalhou-se, pois não houve uma ação eficaz no sentido de ocorrer o reassentamento coletivo para a população atingida pela UHEE. Tanto o CESTE, quanto a interferência da política local dificultaram a escolha de um local onde as famílias pudessem morar juntas e continuar com suas principais atividades exercidas antes da construção da barragem.

Se ele manda nóis escolhê o terreno. Nóis vamo fazê assim, nóis vamo escolhê pra cá da rua de Areia naquele alto pra ele fazê o povoado do povo de Palmatuba. Que ali é bonito, né. Metia as máquina, planiava, fazia vila do pessoal de Palmatuba pra gente colocá até a igreja do nosso padroeiro lá. Mas não, foi diferente. [...] Se o prefeito tivesse feito isso, mas não (Entrevista 23, M. S. S; 25/09/14, 63 anos).

Segundo a entrevistada, a interferência ou falta do interesse político em doar ou adquirir a área pretendida pelos atingidos de Palmatuba impossibilitou o reassentamento coletivo das famílias do extinto povoado. Para a atingida, esta área localizada na cidade de Babaçulândia era adequada para os palmatubenses continuarem as suas vidas.

Apesar das famílias imputarem para a política local a impossibilidade do assentamento na área escolhida pelos atingidos, o Ministério Público Federal indica o CESTE como responsável pelo desinteresse nos assentamentos, pois optou, sobretudo, pela indenização por carta de crédito. A indenização por carta de crédito é estratégia das empresas construtoras de hidrelétricas para minimizar custos e obrigações e foi esta opção de indenização mais aplicada pelo CESTE a fim de liberar as áreas da inundação pela barragem.

Ao longo de todo o processo de discussão de opções de relocação das famílias, o CESTE fez de tudo e mais um pouco para forçar as famílias a aceitarem a opção por receber "carta de crédito" como forma de resolver o problema da forma mais barata e com menos obrigações futuras. Tanto é assim que, de todo a área impactada, um número ínfimo de famílias conseguiu ter acesso a um reassentamento 
A Usina Hidrelétrica Estreito e a Amazônia na política energética brasileira: a desterritorialização dos camponeses ribeirinhos de Palmatuba (TO)
Airton Sieben João Cleps Junior

rural coletivo, nos moldes definidos no Programa Básico Ambiental. (BRASIL, 2010, p. 2).

O mapa 2 mostra a localização da extinta comunidade de Palmatuba situada, anteriormente no município de Babaçulândia (TO), distante cinco quilômetros do centro urbano. $\mathrm{Na}$ situação atual a população encontra-se espalhada em municípios com distância aproximada de até 150 quilômetros da antiga morada.

O mapa 2 mostra que seis famílias entrevistadas moram em área rural, distribuídas em três assentamentos localizados nos municípios tocantinenses de Aragominas, Babaçulândia e Wanderlândia. Em cada assentamento vivem duas famílias. Nas áreas urbanas moram dezenove famílias entrevistadas, distribuídas nas cidades de Araguaína, Babaçulândia e Carolina com catorze, quatro e um representantes, respectivamente.

Mapa 2 - Área de estudo e municípios de imigração das famílias de Palmatuba

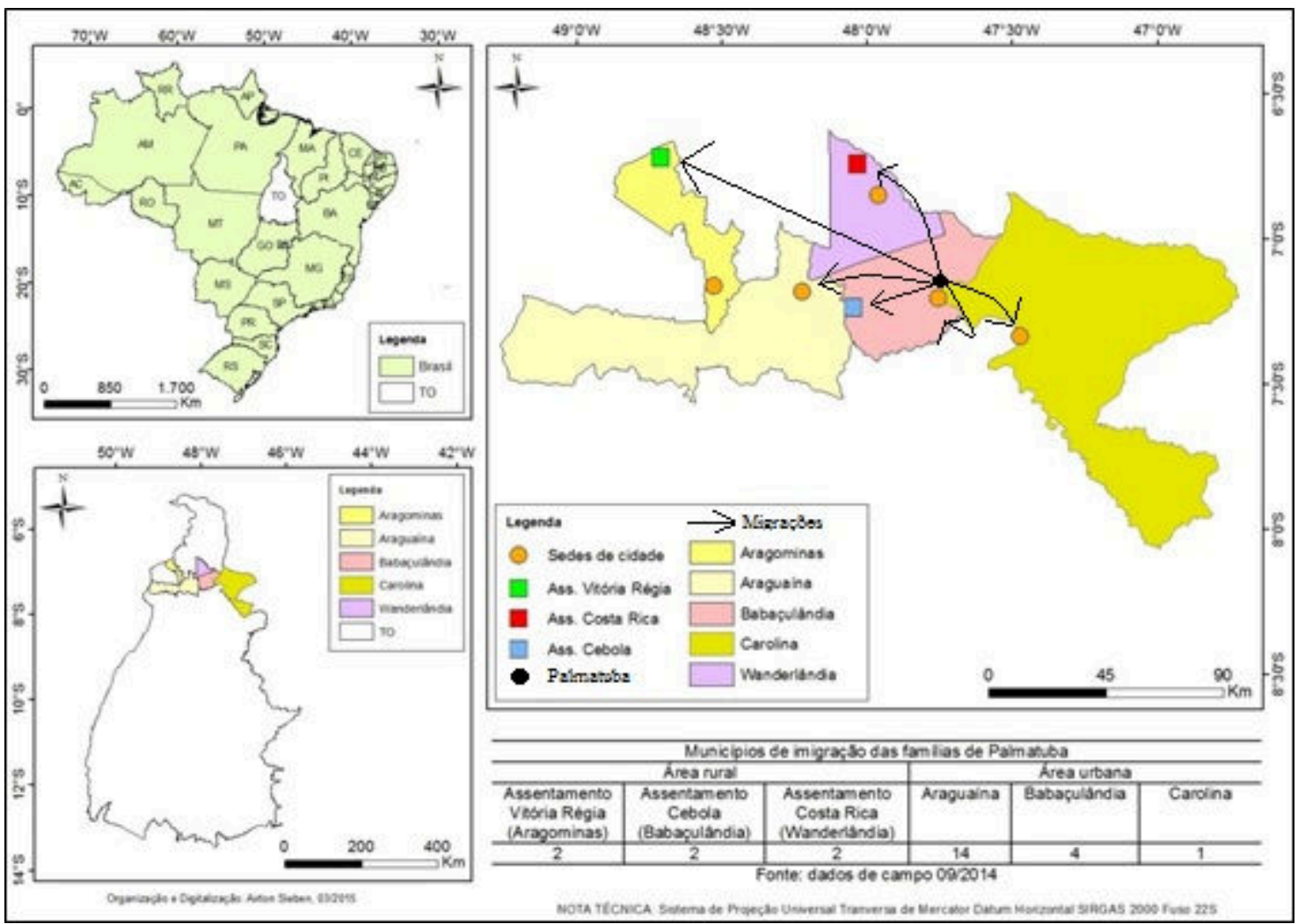

Fonte: IBGE, 2004/2006.

Org. Sieben, 03/2015.

Assim sendo, as famílias se espalharam, não conseguiram morar próximas e continuar a relação de vizinhança (Mapa 2). Das 25 famílias entrevistadas, dezenove 
A Usina Hidrelétrica Estreito e a Amazônia na política energética brasileira: a desterritorialização dos camponeses ribeirinhos de Palmatuba (TO)
Airton Sieben João Cleps Junior

mantiveram residência fixa após a desterritorialização de Palmatuba e outras seis mudaram de endereço. Destas, três alteraram de endereço uma vez, duas mudaram duas vezes e outra mudou de casa três vezes.

Das famílias migrantes, da cidade de Babaçulândia saíram dois representantes e obtiveram terras em área rural, nos assentamentos Cebola, no município de Babaçulândia e assentamento Vitória Régia, localizado próximo ao rio Araguaia, no município de Aragominas. Todos os assentamentos estão localizados no estado do Tocantins (Mapa 2).

Uma entrevistada mora em assentamento, mas transita entre o rural e o urbano, permanecendo em casa de familiares, na cidade de Araguaína. Outra entrevistada faz o caminho inverso, pois adquiriu uma área de terra para cultivar seus alimentos e tem pertencimento com a área rural. Todos os entrevistados que mudaram de endereço uma vez moram na cidade de Araguaína e trocaram de residência nesta cidade com as justificativas de morar próximo aos familiares e ter melhor acesso à infraestrutura urbana (Mapa 2).

Todas as famílias entrevistadas moram no estado do Tocantins, com exceção de uma família que reside na área urbana de Carolina, localizada na margem direita do reservatório da UHEE, no estado do Maranhão (Mapa 1). Uma entrevistada manifestou a intenção de mudar para a cidade de Parauapebas, localizada no estado do Pará, para morar com a filha que trabalha e mora sozinha naquela cidade. Nesta situação há a preocupação por parte da genitora em deixar a filha residindo sozinha em outra cidade, portanto migra para o estado vizinho para acompanhar sua descendente.

As pessoas se ressentem quando precisam migrar. Quem por muito tempo morou num determinado lugar e por força alheia a sua vontade foi expropriado, luta para ficar no local. As pessoas preferem os locais em que as suas lembranças estão mais presentes, pois o espaço se tornou familiar no sentido da categoria lugar e este foi o caso dos atingidos pela UHEE em relação a Palmatuba.

"[...] um grupo não se contenta em manifestar o que sofre, em se indignar e protestar na hora. Ele resiste com toda força as suas tradições e essa resistência tem suas consequências. Ele procura e em parte consegue reencontrar seu antigo equilíbrio nas novas condições" (HALBWACHS, 2006, p. 164).

O desejo de reproduzir as atividades exercidas enquanto moradores do expovoado está presente nas lembranças dos atingidos de Palmatuba e, assim o contato 
A Usina Hidrelétrica Estreito e a Amazônia na política energética brasileira: a desterritorialização dos camponeses ribeirinhos de Palmatuba (TO)

com o ambiente ribeirinho ao qual estavam acostumados. De acordo com o CNEC (2001, p. 73): “O principal bem paisagístico da região é o próprio rio Tocantins, que é utilizado como balneário no período das vazantes..."

Para as margens do rio afluem as populações do interior do Tocantins e do Maranhão, como movimento estimado em 5.000 pessoas por dia nos finais de semana. As prefeituras locais têm participado com a construção de barracos rústicos e com o fornecimento de energia elétrica e segurança. (CNEC, 2001, p. 73).

Os ribeirinhos, barqueiros, pescadores, índios, quebradeiras de coco babaçu, vazanteiros (ribeirinhos que cultivam as planícies de inundação dos rios nas épocas de seca, geralmente de junho a outubro), ilheiros (ribeirinhos que moram nas ilhas dos rios, sobretudo a ilha de São José, atualmente alagada pela UHEE) e outras categorias sociais mantêm relação orgânica com o rio Tocantins. O rio representa importante fonte de renda local nos meses de junho a agosto por oferecer as praias que aparecem com a diminuição pluviométrica no bioma Cerrado e Palmatuba se localizava na margem deste rio, com características peculiares que envolviam este ambiente.

As fotos 1 e 2 mostram a rua principal de Palmatuba. As casas eram de alvenaria, cobertas de telha e paredes de tijolos sem reboco. As telhas e os tijolos foram produzidos na própria comunidade. As casas eram construídas de adobe e algumas eram cobertas com palha de coco babaçu.

Fotos 1 e 2 - Casas e eletricidade em Palmatuba antes da formação do lago da UHEE

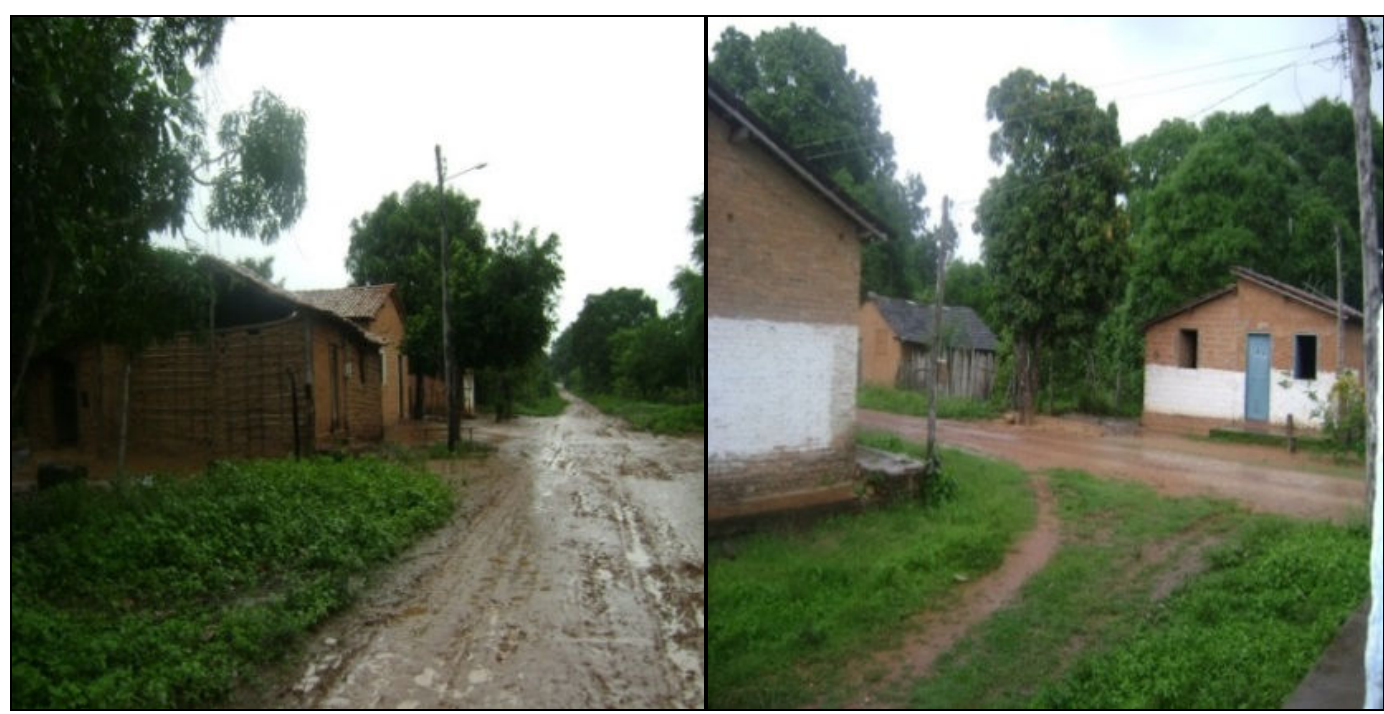

Fonte: Araújo, 02/2008.

Org: Sieben, 12/2014. 
A Usina Hidrelétrica Estreito e a Amazônia na política energética brasileira: a desterritorialização dos camponeses ribeirinhos de Palmatuba (TO)
Airton Sieben João Cleps Junior

Havia a presença de árvores na frente das casas e, principalmente, muitas eram frutíferas nos quintais, fornecendo sombra. A rede elétrica era composta de postes de madeira, mostrando sinais da década de 1980, quando chegou a eletricidade no local. Naquele tempo os postes de concreto ainda não eram frequentes, principalmente em áreas rurais da Amazônia Legal. A estrada sem pavimentação mostra a realidade de uma comunidade localizada outrora às margens do rio Tocantins.

Para quem visitou o local uma única vez pensou em se tratar de uma vila sem significado e desprovida de qualquer infraestrutura. Esta visão preconceituosa serviu de justificativa para o empreendedor trazer o "progresso", contudo o que se seguiu foi um desastre para muito atingidos que sentem saudades do lugar, seguida de injustiças na indenização, desestruturação, incertezas, dificuldades e a necessidade de reconstruir vidas.

As fotos 3 e 4 apresentam a transformação da paisagem de Palmatuba em dois momentos, representada pela única estrada de acesso ao ex-povoado. Na foto à esquerda aparece a estrada principal antes da formação do reservatório da UHEE. É perceptível a estrada de terra, por onde circularam veículos, pessoas e animais antes da formação do reservatório. Dos dois lados da estrada havia vegetação e as casas se localizavam ao longo da mesma.

Fotos 3 e 4 - Transformação da antiga estrada de acesso ao povoado Palmatuba

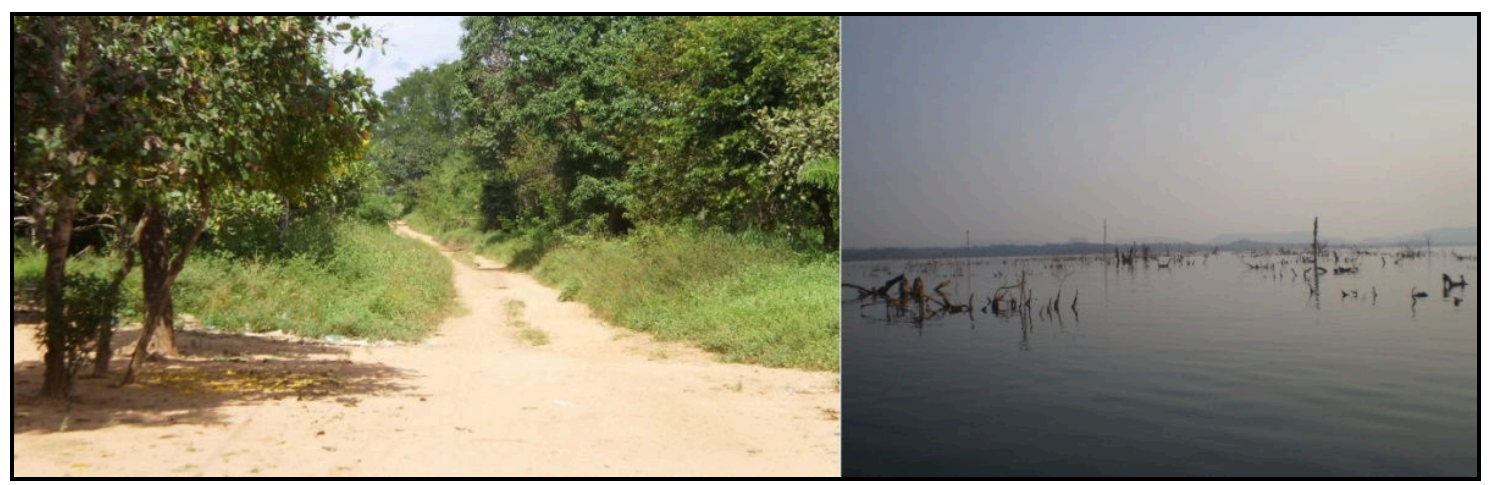

Autor: Sieben, 05/06/2009 e 01/10/2014.

$\mathrm{Na}$ fotografia a direita se percebe resquícios da antiga estrada de acesso para Palmatuba. O caminho percorrido pelo barco está com árvores praticamente em fase final de deterioração. Em breve a linha sem a vegetação em decomposição que representa a antiga estrada estará irreconhecível. Em assim sendo, nem mesmo quem acompanhou a transformação da paisagem local poderá localizar a ex-comunidade. 
Conforme Leturcq (2007, p. 13): “As barragens no Brasil criam, por conseguinte, modificações importantes nos espaços rurais, nas paisagens, bem como nas populações e nas dinâmicas territoriais". A barragem representou um ponto de ruptura no modo de vida, alterando o sentido de pertencimento da população regional atingida pela UHEE.

Quase todos os atingidos entrevistados lembraram do lugar e as lembranças foram diversas, sendo as atividades desenvolvidas com o rio Tocantins e a quebra do coco babaçu as mais comentadas. "Assim, vez assim, quando é verão né, no mês de junho e julho quando começa a ventá, assim eu lembro direitinho de lá, pescá no rio, assim quando tava secando" (Entrevista 1, C. M. M; 17/09/2014, 42 anos). A lembrança para a família é no sentido de lazer, principalmente nos meses de junho a outubro, quando a vazão do rio Tocantins diminuía por causa do período de menor pluviosidade, aparecendo as praias nas margens do rio.

\footnotetext{
Meu Deus, toda noite eu lembro de tudo, quando fecho o olho, assim. Vejo tudinho. Sonho com minha casa. Quando chove assim, agora mesmo quando deu as primeiras chuvas que me recordou tanto que chorei. A vizinha perguntou: que é? Não sinhá, é lembrança do meu lugar. Lembrança de descê pro rio. Lembro da casa do seu Ricardo. Tudo é recordação. Não esqueço, não. Só quando eu morrê. E vou lá. De vez em quando, assim quando passa o banzeiro a gente passa. Eu conheço tudinho. Onde era a casa de fulano. Agora mesmo não pode conhecê porque os pau tão caindo tudo. Os pé de árvore que tinha no quintal, na porta de alguém tá apodrecendo, tá caindo, mas eu não esqueço não (Entrevista 19, M. O. F. S; 24/09/2014, 49 anos).
}

As lembranças dos atingidos são inúmeras, retratando o sentimento atual, envolvendo de forma geral, as situações psicológica e socioeconômica das famílias atingidas. Após cinco anos de desterritorialização pela UHEE, das 25 famílias entrevistadas, duas se sentem em situação ótima e três em situação boa, correspondendo a $8 \%$ e $12 \%$, respectivamente. Na opção regular têm-se seis famílias, representando $24 \%$. Com sentimento ruim e péssimo há três e um entrevistados, respectivamente, o que representa $12 \%$ e $4 \%$, consecutivamente (Gráfico 5). 
A Usina Hidrelétrica Estreito e a Amazônia na política energética brasileira: a desterritorialização dos camponeses ribeirinhos de Palmatuba (TO)

Gráfico 5 - Pós desterritorialização: a situação dos atingidos de Palmatuba em 2014

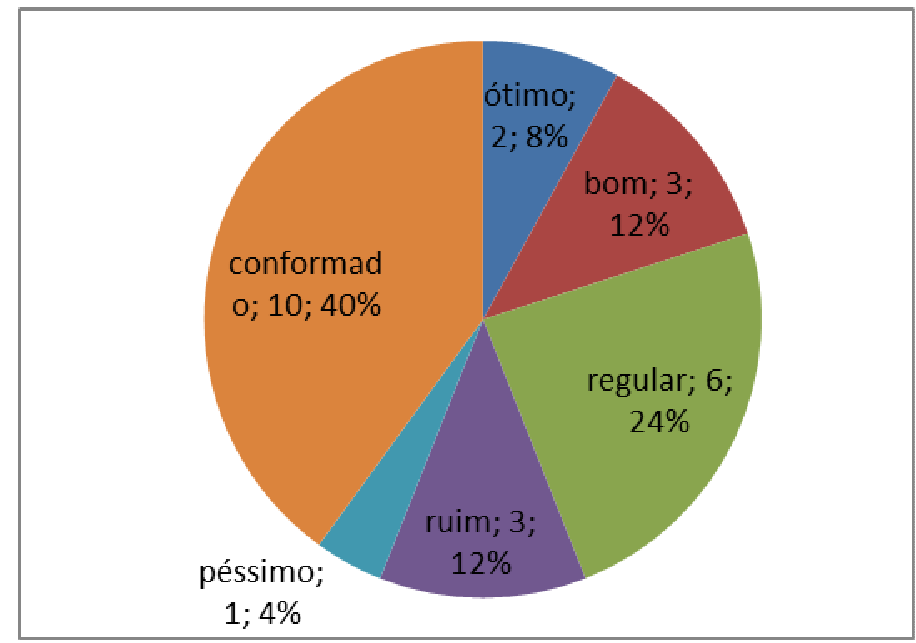

Fonte: dados de campo 09/2014

Dez famílias entrevistadas, ou seja, $40 \%$, afirmaram se sentirem conformados na condição atual. Certos entrevistados manifestaram que a situação de conformismo é uma forma de aceitar a situação e continuarem suas vidas com menor sentimento de revolta e injustiça. De forma geral, foi perceptível o grau de insatisfação dos atingidos.

Muitos dos atingidos de Palmatuba estão na justiça para reivindicar a diferença paga pela carta de crédito no valor de $\mathrm{R} \$ 45.000,00$ no momento da desapropriação nos anos de 2008 e 2009 e que segundo a asserção defendida pelo advogado dos atingidos deveria ter sido no valor aproximado de R\$ 100.000,00. Destarte, há um valor sentimental (pertencimento ao lugar) e material (plantações, olarias, terras e outros) que não foram contemplados pela indenização, aumentando a situação de insegurança, desconforto e injustiça.

Observou-se que a UHE Estreito não trouxe melhoras significativas para a população. O discurso do progresso e da melhoria de vida não se concretizou e as indenizações não compensaram toda angústia e incertezas sofridas durante o processo de emigração. Portanto, conclui-se que a reterritorialização é uma incerteza e as famílias necessitam de tempo para se reencontrarem e conseguirem se adaptar ao novo modo de vida. A reconstituição do sentido da categoria geográfica lugar é um processo lento. 
A Usina Hidrelétrica Estreito e a Amazônia na política energética brasileira: a desterritorialização dos camponeses ribeirinhos de Palmatuba (TO)
Airton Sieben João Cleps Junior

\section{Considerações finais}

As políticas de desenvolvimento territorial aparentemente se mostram capazes de dinamizar o território, contudo os programas estatais estão aliados com os agentes/atores representantes do grande capital (trans)nacional. Na outra ponta os pequenos camponeses são prejudicados pelas políticas nacionais desenvolvimentistas como a construção de hidrelétricas que são orquestradas por um Estado aparentemente neutro.

As indústrias eletrointensivas de cimento, cerâmica, ferro-ligas, mineração, pelotização, papel, têxtil, celulose, ferro-gusa, aço, alimentos, materiais não ferrosos e outros metálicos consomem praticamente $40 \%$ da energia elétrica produzida no Brasil. Grande parte destas indústrias agrega pouco valor ao produto transformado, necessitando de muita energia por unidade produzida. É para o setor industrial, alto consumidor de energia, que aumentará a demanda energética futura.

Análises de perspectivas futuras com base em documentos do Estado brasileiro indicam que este quadro se manterá até o ano de 2030. Assim sendo, não haverá uma política capaz de mudar o atual quadro de dependência hidrelétrica e o setor se comporta como uma forma de transferir riquezas brasileiras e verbas públicas ao grande capital (trans)nacional.

Os consórcios hidrelétricos são formados por bancos, indústrias eletrointensivas, grandes construtoras e empresas multinacionais. Ocorre uma união entre capitalismo nacional com o internacional sob os auspícios do Estado brasileiro para a concentração do capital obtendo lucros exorbitantes com a hidreletricidade no território brasileiro. Nesta perspectiva, a população ribeirinha da Amazônia sofre os efeitos da desterritorialização e da expropriação de suas terras causadas por ações políticas e econômicas que transformam a região Norte numa monocultura energética.

Muitas das empresas que compõem os consórcios formadores de hidrelétricas gozam de privilégios. Nas campanhas políticas as grandes empresas aproximam-se dos futuros governantes e, posteriormente são beneficiadas com contratos e licitações duvidosas com altos orçamentos. Em assim sendo, garantindo lucros vultosos para as empresas, propina à política e financiados pela sociedade.

O CESTE, consórcio formado pelas empresas GDF Suez-Tractebel (francesa), Alcoa (estadunidense), Vale (brasileira) e Grupo Camargo Correa (brasileira) construiu a UHEE. O consórcio tem contrato de concessão por 35 anos. Nesta união ficou evidente a 
A Usina Hidrelétrica Estreito e a Amazônia na política energética brasileira: a desterritorialização dos camponeses ribeirinhos de Palmatuba (TO)

associação do capital nacional/internacional para receberem lucros vultosos com as tarifas pagas pela energia elétrica. Ressalta-se ainda que as empresas Alcoa e Vale usam a energia elétrica em seus próprios pátios industriais, diminuindo o custo de produção.

A região da Amazônia brasileira é a maior responsável para aumentar a necessidade energética futura do Brasil. O Brasil passará dos 109.578MWh de energia produzida no ano de 2010 para $171.138 \mathrm{MWh}$ no ano de 2020. A expectativa de aumento será de $61.560 \mathrm{MWh}$ e a Amazônia responderá por $28.209 \mathrm{MWh}$ produzidos pelas mais de quatrocentos hidrelétricas construídas, em construção e em projeto.

A matriz energética brasileira está baseada na produção hídrica, podendo paralisar ou diminuir o crescimento econômico, caso haja um racionamento hídrico causado pela escassez da chuva, apesar de todo planejamento energético efetuado pelo SIN. Ainda há um perigo maior causado pela concentração de água em reservatórios sob o controle de empresas (trans)nacionais que vislumbram enormes lucros na mercantilização da água no futuro, com outras finalidades que perpassam a produção de energia elétrica, como por exemplo a expectativa de uso urbano.

A crise hídrica e seu reflexo na crise elétrica sinalizam que é urgente um programa governamental que diversifique as fontes elétricas, diminuindo o oligopólio hidrelétrico sem interferir na produção elétrica que pode advir de outras fontes. O Brasil tem diversas formas de produzir eletricidade em seu rico e amplo território.

É o momento para que novas tecnologias sejam amplamente utilizadas como a bioeletricidade, maremotriz, eólica, solar, biogás, aterros sanitários e outros. Por outro lado deve-se lembrar que leis, normas e a preferência nacional pela hidreletricidade estão voltados para atender interesses de setores econômicos interessados em construir grandes barragens e lucrar com a geração de energia e com o mercado futuro da água. Desta forma, as necessidades elétricas da população ficam em segundo plano.

A alternativa elétrica em partes das regiões Norte e Nordeste seria o coco babaçu que dentre muitas utilidades pode fornecer energia elétrica, por ser um rico material energético, tanto do óleo extraído de suas amêndoas quanto da combustão da casca deste fruto. O Estado deve promover políticas públicas, facilitar normas, estimular a produção e o uso de alternativas energéticas.

O estado do Tocantins busca a modernização de seu território com políticas públicas territoriais baseadas no agronegócio e na hidreletricidade, com o potencial 
A Usina Hidrelétrica Estreito e a Amazônia na política energética brasileira: a desterritorialização dos camponeses ribeirinhos de Palmatuba (TO)

hidrelétrico muito além da sua necessidade. Os grandes rios, em especial o Tocantins, já têm hidrelétricas em funcionamento e outras a serem construídas, transformando o canal fluvial em uma sucessão de lagos artificiais.

Após cinco anos de desterritorialização as pessoas atingidas pela UHEE estão percebendo que foram enganadas, lesadas e perderam com todo o processo de desterritorialização. Os atingidos estão montando e desvendando o complexo jogo formulado pelo CESTE e o aparato estatal. Os fatos estão ficando claros e aos poucos os atingidos elucidam as formas e os meios utilizados pelo CESTE e demais atores para ludibria-los.

Salienta-se que somente num momento posterior os atingidos percebem o quanto são lesados nos grandes projetos políticos e econômicos. O trabalho de conscientização no momento da expropriação se tornou complexo no caso da UHEE, pois havia e há ainda muitos interesses por trás da hidrelétrica. Até mesmo movimentos sociais organizados foram desacreditados pelos agentes e atores interessados na construção da barragem.

A UHEE significou prejuízo, atraso de vida, transtorno, injustiça, perda do modo de vida e de familiares. São várias histórias que sofreram uma ruptura no seu modo de vida. $\mathrm{Na}$ atual circunstância os atingidos estão tentando reconstruir o sentido de pertencimento, pois o lugar não existe mais.

Transcorridos cinco anos de emigração a luta dos atingidos continua reivindicando o que lhes é de direito: indenização justa. Os atingidos estão com ação na justiça para cobrar a diferença de $\mathrm{R} \$ 55.000,00$ sobre a carta de crédito, opção que o CESTE adotou na indenização, diminuindo custos e obrigações com os atingidos pela UHEE.

Isto mostra que a reterritorialização gera muitas dúvidas, pois no caso em estudo ela foi incompleta, fragmentada ou, no mínimo, as famílias tiveram que se conformar com a desterritorialização. Há a necessidade de acompanhamentos futuros para se ter a dimensão do significado da UHEE para os atingidos de Palmatuba.

Muitas dúvidas ainda pairam sobre a UHEE após cinco anos, considerando o fato de que é necessária outra política elétrica no Brasil que seja alternativa a matriz baseada na hidreletricidade. Na atual política energética, deve haver maior atenção 
estatal, diminuindo conflitos e transtornos onde os direitos sociais, econômicos e culturais dos atingidos devem ser mantidos.

\section{Notas}

${ }^{1} \mathrm{O}$ artigo é resultado de estágio pós-doutoral desenvolvido no Programa de Pós-Graduação em Geografia (PPGEO) do Instituto de Geografia (IG) da Universidade Federal de Uberlândia (UFU), no período de maio de 2014 e abril de 2015, contando com o apoio da Coordenação de Aperfeiçoamento de Pessoal de Nível Superior (CAPES) com bolsa do Programa Nacional de Pós-Doutorado (PNPD).

${ }^{2}$ A aprovação do projeto por um CEP tem como efeito maior segurança aos entrevistados e entrevistador, sobretudo ao se tratar de temas polêmicos. No caso específico, os pontos particulares foram as emoções e as lembranças de Palmatuba, além dos esclarecimentos sobre o tema e os objetivos da pesquisa, aos entrevistados.

\section{Referências}

ALVES, José. As revoltas dos trabalhadores em Jirau (RO): degradação do trabalho represada na produção de energia elétrica na Amazônia. 2014. $671 \mathrm{f}$. Tese (Doutorado em Geografia) - Faculdade de Ciências e Tecnologia, UNESP/ Presidente Prudente, 2014.

ARAÚJO, Rita P. Impacto sócio - ambiental na comunidade

Palmatuba/Babaçulândia/TO: influência da construção da Usina Hidrelétrica de Estreito (UHE). 2009. 31 f. (Monografia) - Curso de Geografia UFT/Araguaína, 2009.

BRASIL, Ministério de Minas e Energia/Empresa de Pesquisa Energética. Plano Decenal de Expansão de Energia 2021. Brasília: MME/EPE, 2012387 p. Disponível em: <http://www.epe.gov.br/PDEE/20130326_1.pdf> Acesso em 10 nov. 2014.

BRASIL, Ministério de Minas e Energia/Empresa de Pesquisa Energética. Plano Decenal de Expansão de Energia 2020. Brasília: MME/EPE, 201180 p. Disponível em: <http://www.mme.gov.br/mme/galerias/arquivos/noticias/2011/SUMARIOPDE2020.pdf $>$ Acesso em 10 nov. 2014.

BRASIL, Ministério Público Federal. $1^{\text {a }}$ Vara da Seção Judiciária do Estado do Tocantins. Processo $n^{\circ}$ 4244-56.2010.4.01.4300. Ação de Desapropriação. Palmas, 28 de julho de 2010. Álvaro Lotufo Manzano (Procurador da República). 4 p.

BRASIL, Lei $\mathrm{n}^{\circ}$ 11.079/2004, de 30, de dezembro de 2004. Disponível em: $<$ http://www.planalto.gov.br/ccivil_03/_ato2004-2006/2004/lei/11 1079.htm> Acesso em: 10 ago. 2014.

BRASIL, Relatório 1. Disponível em: < http://www.brasil.gov.br/pac/pac-2/pac-2relatorio-1> Acesso em: 11 fev. 2012.

BRASIL, Resolução ${ }^{\circ}$ 466/12, de 12, de dezembro de 2012. Disponível em: $<$ http://conselho.saude.gov.br/resolucoes/2012/Reso466.pdf $>$ Acesso em: 10 jun. 2014. 
BRASIL. Ministério de Minas e Energia. Plano Nacional de Energia 2030. Brasília, 2007. 12 v. 372 p. Disponível em: <http://www.epe.gov.br/PNE/20080512_2.pdf > Acesso em: 01 set. 2014.

CESTE (Consórcio Estreito Energia). Disponível em: <http://www.uheestreito.com.br/ver_secao.php?session_id=70> Acesso em 25 de nov. 2014.

CESTE (Consórcio Estreito Energia). Disponível em: <http://www.uheestreito.com.br/ver_secao.php?session_id=72 $\geq$ Acesso em: $25 /$ de nov. 2014

CNEC. Estudos de Viabilidade da UHE Estreito: Relatório de Impacto Ambiental RIMA, 2001. 267 p.

DÍAZ, Mirta C. Introducción al estudio del pensamiento latinoamericano. La Habana: Editorial Pueblo y Educación, 2012. 104 p.

FOSCHIERA, Atamis A. Da Barranca do rio para a periferia dos centros urbanos: a trajetória do Movimento dos Atingidos por Barragens face às políticas do setor elétrico no Brasil. 2009. 344 f. Tese (Doutorado em Geografia) - Faculdade de Ciências e Tecnologia, UNESP/ Presidente Prudente, 2009.

HALBWACHS, Maurice. A memória coletiva. Tradução de Beatriz Sidou. São Paulo: Centauro, 2006. 224 p.

HOUTART, François. Energía y desarrollo. In: . La agroenergía: solución para el clima o salida de la crisis para el capital. Traducción de Lourdes Arencibia. La Habana: Ruth Casa Editorial, 2009. 262 p. cap. 1, p. 5-28.

IBGE (Instituto Brasileiro de Geografia e Estatística). Divisão Regional. (2004).

Disponível em:

$<\mathrm{ftp}$ //geoftp.ibge.gov.br/mapas_tematicos/mapas_murais/brasil_2004.pdf $>$ Acesso em: 31 out. 2011.

IBGE (Instituto Brasileiro de Geografia e Estatística). Divisão Regional. (2006).

Disponível em:

<ftp://geoftp.ibge.gov.br/mapas/tematicos/mapas_murais/logistica/energia/2006.pdf> Acesso em: 31 out. 2011.

LETURCQ, Guillaume. A diversidade dos atingidos por barragens no Brasil. 2007. 15 p. Disponível em: $<$ http://halshs.archives-ouvertes.fr/docs/00/38/10/79/PDF/Artigo__II_Encontro_Barragens_-_G._Leturcq.pdf> Acesso em: 27 jan. 2012.

MARTINS, José S. Os camponeses e a política no Brasil: as lutas sociais no campo e seu lugar no processo político. Petrópolis: Vozes, 1981. 185 p.

MEIHY, José C. S. B. História oral: reputação e espaço de conhecimento. In:

Manual de história oral. 5. ed. São Paulo: Loyola, 2005. 291 p. cap. 1, p. 14-57. 
PINTO, Lúcio F. Hidrelétricas na Amazônia: predestinação, fatalidade ou engodo? Belém: Edição Jornal Pessoa, 2002. 124 p.

SIEBEN, Airton. Estado e Política Energética: a desterritorialização da Comunidade rural de Palmatuba em Babaçulândia (TO) pela Usina Hidrelétrica Estreito 2012. 203 f. Tese (Doutorado) - Instituto de Geografia, Universidade Federal de Uberlândia, UFU/Uberlândia, 2012.

SIEBEN, Airton; CLEPS, João J. Entrevista: instrumento de pesquisa no estudo da Comunidade de Palmatuba (Babaçulândia/TO). In: MARAFON, Glaucio J; RAMIRES, Julio C. de L; RIBEIRO, Miguel A; e PESSÔA Vera L. S. Pesquisa qualitativa em Geografia: reflexões teórico-conceituais e aplicações. Rio de Janeiro: EdUERJ, 2013. 542 p. p. $241-256$.

WHITAKER, Dulce C. A. et. al. A transcrição da fala do homem rural: fidelidade ou caricatura? In. WHITAKER, Dulce C. A. Sociologia rural: questões metodológicas emergentes. Presidente Wenceslau/SP: Letras à Margem, 2002. 256 p. p. 115-120. 